\title{
EFFECTS OF PRESSURE-CONTROLLED AND VOLUME-CONTROLLED VENTILATION ON HEMODYNAMIC AND RESPIRATORY PARAMETERS IN PATIENTS DURING LAPAROSCOPIC CHOLECYSTECTOMY
}

\author{
Mirko Mihalj ${ }^{1}$, Dajana Vladić ${ }^{1}, Z_{\text {Zoran Karlović }}{ }^{1}$ Željka Zadro ${ }^{1}$ and Višnja Majerić Kogler ${ }^{2}$ \\ ${ }^{1}$ Mostar University Hospital, Department of Anesthesia, Resuscitation and Intensive Care, \\ Mostar, Bosnia and Herzegovina; ${ }^{2}$ University of Zagreb, School of Medicine, Zagreb, Croatia
}

\begin{abstract}
SUMMARY - Many papers have been published investigating the effects of intraoperative mechanical ventilation on the incidence of intra- and postoperative respiratory complications. The potential advantages of protective pressure over volume-controlled ventilation mode during laparoscopic surgery have yet to be proven. This study included 60 patients aged between 18 and 70 with ASA score 1-3, body mass index (BMI) $\leq 35 \mathrm{~kg} / \mathrm{m}^{2}$, and without prior history of chronic respiratory diseases, who were scheduled for laparoscopic cholecystectomy under general anesthesia. Patients were assigned randomly to protective pressure or volume-controlled mechanical ventilation mode. The initial results showed no significant differences in respiratory and hemodynamic parameters between the groups. Comparison of patients with $\mathrm{BMI} \geq 25$ showed significantly lower peak inspiratory pressure (Ppeak) at 15 (18.52 vs. $21.83 \mathrm{~cm} \mathrm{H} 2 \mathrm{O}, \mathrm{p}=0.022), 30$ (18.73 vs. $21.83 \mathrm{~cm} \mathrm{H2O,p=0.009)}$ and 45 (18.94 vs. $22.667 \mathrm{~cm} \mathrm{H2O,p=0.010)} \mathrm{minutes} \mathrm{after} \mathrm{tracheal} \mathrm{intubation} \mathrm{in} \mathrm{the} \mathrm{pressure-con-}$ trolled ventilation $(\mathrm{PCV})$ group. Other measured parameters were of similar characteristics. It is concluded that PCV and volume-controlled ventilation were equally effective in maintaining adequate ventilation, oxygenation and hemodynamic stability in the groups of patients observed. However, comparison of obese patients revealed some advantages of PCV which, given the present pace of change, should be additionally investigated.
\end{abstract}

Key words: Respiration, artificial; Laparoscopy; Anesthesia, general; Intubation, intratracheal; Respiration; Obesity; Case reports

\section{Introduction}

General anesthesia causes decline in vital lung capacity, functional residual capacity and lung compliance, especially during laparoscopic cholecystectomy due to patient positioning (Trendelenburg position) and creation of pneumoperitoneum, which causes increased intra-abdominal and intrathoracic pressure.

Correspondence to: Mirko Mihalj, MD, Mostar University Hospital, Department of Anesthesia, Resuscitation and Intensive Care, Kneza Trpimira 14, Mostar, Bosnia and Herzegovina E-mail:mmmihalj@gmail.com

Received January 11, 2016, accepted October 24, 2016
This can lead to repeated closure of small airways and occurrence of atelectases. The majority of otherwise healthy patients are capable to successfully compensate for these changes, but obese patients and those with chronic respiratory diseases are susceptible to development of numerous complications such as intraoperative hypoxia, barotrauma and volutrauma during laparoscopic procedures ${ }^{1}$.

In addition, in recent years, many papers have been published investigating the effects of intraoperative mechanical ventilation on the incidence of perioperative and postoperative respiratory complications ${ }^{2}$. Alveolar collapse can be prevented by applying continu- 
ous positive end-expiratory pressure and tidal volume should be decreased to limit pulmonary overdistention. This concept is known as protective mechanical ventilation and is now used in the treatment of respiratory disorders requiring mechanical ventilation ${ }^{3}$. By using protective volume- or pressure-controlled mechanical ventilation, it is possible to optimize respiratory and hemodynamic functions during surgery ${ }^{4}$.

Volume-controlled ventilation (VCV) is considered to be the most popular mode for intraoperative use. It is a mode of ventilation controlled by tidal volume and respiratory frequency as constant parameters, with variable inspiratory pressures. Although popular, $\mathrm{VCV}$ is not without drawbacks because high peak pressures (Ppeak) can sometimes force anesthesiologists to change the preset tidal volume and frequency values.

Pressure-controlled ventilation (PCV) has inspiratory pressure and respiratory frequency as constant parameters, while the tidal volume achieved depends on lung compliance and resistance. Decelerating inspiratory flow pattern in PCV ventilation is associated with a lower incidence of airway barotrauma with high peak pressures, while the increased mean inspiratory pressure (Pmean) has positive effects on oxygenation. However, tidal volume can vary greatly during surgery.

The aim of this clinical trial was to compare the effects of the VCV and PCV protective modes of mechanical ventilation on pulmonary mechanics, gas exchange, and hemodynamic parameters of patients during laparoscopic cholecystectomy.

\section{Patients and Methods}

The study included 60 patients aged between 18 and 70, with the American Society of Anesthesiologists (ASA) physical status 1-3 and body mass index $(\mathrm{BMI})<35 \mathrm{~kg} / \mathrm{m}^{2}$, who were scheduled for laparoscopic cholecystectomy under general anesthesia at the Mostar University Hospital. All patients were without prior history of chronic respiratory diseases. Exclusion criteria were intraoperative usage of an airway device other than tracheal tube and a requirement for mechanical ventilation in the postoperative period.

Patients were assigned randomly to two groups, VCV or PCV, using pre-sealed opaque envelopes prepared and drawn by an independent observer. Patients assigned to the first group were ventilated with protec- tive $\mathrm{VCV}$ with tidal volume set at $7 \mathrm{~mL} / \mathrm{kg}$. In the second, $\mathrm{PCV}$ group, the ventilator was adjusted so that the preset pressure attained the desired tidal volume of 7 $\mathrm{mL} / \mathrm{kg}$ with a variation of $5 \%$. The ratio of inspiratory to expiratory time (1:2), fraction of inspired oxygen FIO2 (0.4) and positive end-expiratory pressure of 7 $\mathrm{cm} \mathrm{H}_{2} \mathrm{O}$ were the same in both groups. Variations in respiratory rate were allowed to maintain the values of end-tidal carbon dioxide in a range of $28-40 \mathrm{~mm} \mathrm{Hg}$.

Induction in general anesthesia consisted of midazolam $0.04 \mathrm{mg} / \mathrm{kg}$, followed by fentanyl $1 \mu \mathrm{g} / \mathrm{kg}$, propofol $1-2 \mathrm{mg} / \mathrm{kg}$ until adequate depth of anesthesia achieved bispectral index (BIS) score $\leq 60$. Tracheal intubation was performed after administration of 0.4 $\mathrm{mg} / \mathrm{kg}$ atracurium. Anesthesia was maintained with a mixture of $\mathrm{O} 2(40 \%)$ and $\mathrm{N} 2 \mathrm{O}(60 \%)$, along with minimal alveolar concentration (MAC) sevoflurane $=1$. Intravenous fluids in the form of $0.9 \% \mathrm{NaCl}, 20$ $\mathrm{mL} / \mathrm{min}$ were administered.

During surgery, the abdominal cavity was insufflated with $\mathrm{CO} 2$ with patients in the supine position, to maximum intra-abdominal pressure of $12 \mathrm{~mm} \mathrm{Hg}$, and then patients were tilted in anti-Trendelenburg position by $20^{\circ}$ and the same position was maintained throughout the procedure.

We recorded heart rate (HR), mean arterial pressure (MAP) and arterial oxygen saturation $(\mathrm{SaO} 2)$ at 4 time intervals: before induction of general anesthesia (baseline measurements), and at 15,30 and 45 minutes after tracheal intubation. We also recorded end-tidal $\mathrm{CO} 2$, Ppeak and Pmean inspiratory pressure at 3 time intervals: at 15, 30 and 45 minutes after tracheal intubation.

Dräger Primus (Drägerwerk AG \& Co. KGaA, Lübeck, Germany) was used as anesthesia workstation. All patients were continuously monitored using electrocardiography (ECG), pulse oximetry and noninvasive arterial pressure (Dräger Infinity Delta monitor, Drägerwerk AG \& Co. KGaA, Lübeck, Germany). BIS was used to monitor the level of consciousness (BIS technology, Aspect Medical Systems, Meern, The Netherlands).

Data analysis was performed using SPSS for Windows (version 17.0, SPSS Inc., Chicago, Illinois, $\mathrm{SAD})$. Results were expressed as mean and standard deviation $(\mathrm{M} \pm \mathrm{SD})$. T-test for independent samples was used to test statistically significant differences between the groups. The level of $p<0.05$ was considered 
Table 1. Patient characteristics and baseline data

\begin{tabular}{|ll|l|l|}
\hline & & $\begin{array}{l}\text { PCV } \\
(\mathrm{n}=30)\end{array}$ & $\begin{array}{l}\text { VCV } \\
(\mathrm{n}=30)\end{array}$ \\
\hline Age (years) & & $44 \pm 14$ & $48 \pm 14$ \\
& male & 15 & 15 \\
Gender: & female & 15 & 15 \\
& & $81 \pm 13$ & $78 \pm 16$ \\
Weight $(\mathrm{kg})$ & & $175 \pm 11$ & $174 \pm 9$ \\
Height $(\mathrm{cm})$ & & $26 \pm 3$ & $25 \pm 4$ \\
BMI $\left(\mathrm{kg} / \mathrm{m}^{2}\right)$ & & $84 \pm 15$ & $85 \pm 14$ \\
HR (beats/min) & $108 \pm 14$ & $107 \pm 12$ \\
MAP (mm Hg) & $98 \pm 1$ & $98 \pm 1$ \\
SpO2 (\%) & & 98 \\
\hline
\end{tabular}

Values are mean \pm standard deviation $(\mathrm{SD})$; $\mathrm{HR}=$ heart rate; $\mathrm{MAP}$ $=$ mean arterial pressure $\mathrm{PCV}=$ pressure-controlled mechanical ventilation; $\mathrm{VCV}=$ volume-controlled mechanical ventilation; $\mathrm{BMI}=$ body mass index; $\mathrm{SpO} 2=$ arterial oxygen saturation significant. The results were first presented by comparing original groups of 30 patients regardless of body mass and then we compared only patients with BMI $>25$ in each group. All patients were informed about the nature of the study and data to be collected. All patients signed an informed consent.

\section{Results}

The two groups were well matched according to patient characteristics (gender, age and BMI) and baseline data (Table 1). Table 2 shows the values of HR, MAP, Ppeak and plateau inspiratory pressure (Pplateau), end-tidal $\mathrm{CO} 2$ and $\mathrm{SaO} 2$ recorded at three time intervals. There were no major differences in the values of lung mechanics, gas exchange and hemodynamic parameters between the groups. The only sig-

Table 2. Hemodynamic and respiratory data recorded at three time intervals: T1 - 15 minutes after tracheal intubation; T2 - 30 minutes after tracheal intubation; and T3 - 45 minutes after tracheal intubation

\begin{tabular}{|c|c|c|c|c|c|c|}
\hline & \multicolumn{2}{|l|}{ T1 } & \multicolumn{2}{|l|}{$\mathrm{T} 2$} & \multicolumn{2}{|l|}{ T3 } \\
\hline & $\begin{array}{l}\text { PCV } \\
(\mathrm{n}=30)\end{array}$ & $\begin{array}{l}\text { VCV } \\
(\mathrm{n}=30)\end{array}$ & $\begin{array}{l}\mathrm{PCV} \\
(\mathrm{n}=30)\end{array}$ & $\begin{array}{l}\mathrm{VCV} \\
(\mathrm{n}=30)\end{array}$ & $\begin{array}{l}\mathrm{PCV} \\
(\mathrm{n}=30)\end{array}$ & $\begin{array}{l}\mathrm{VCV} \\
(\mathrm{n}=30)\end{array}$ \\
\hline HR (beats/min) & $77 \pm 16$ & $78 \pm 17$ & $73 \pm 13$ & $78 \pm 12$ & $72 \pm 13$ & $76 \pm 11$ \\
\hline $\operatorname{MAP}(\mathrm{mm} \mathrm{Hg})$ & $97 \pm 15$ & $91 \pm 10$ & $103 \pm 14$ & $100 \pm 16$ & $100 \pm 15$ & $98 \pm 12$ \\
\hline Ppeak $\left(\mathrm{cm} \mathrm{H}_{2} \mathrm{O}\right)$ & $17 \pm 3$ & $18 \pm 4$ & $17 \pm 3$ & $18 \pm 4$ & $17 \pm 4$ & $18 \pm 4$ \\
\hline Pplateau $\left(\mathrm{cm} \mathrm{H}_{2} \mathrm{O}\right)$ & $16 \pm 4$ & $16 \pm 3$ & $17 \pm 4$ & $16 \pm 4$ & $17 \pm 4$ & $16 \pm 4$ \\
\hline etCO2 $(\mathrm{mm} \mathrm{Hg})$ & $32 \pm 3$ & $33 \pm 3$ & $32 \pm 3$ & $33 \pm 4$ & $32 \pm 3$ & $32 \pm 4$ \\
\hline $\mathrm{SpO} 2(\%)$ & $99 \pm 1$ & $99 \pm 1$ & $99 \pm 1$ & $99 \pm 1$ & $99 \pm 1$ & $99 \pm 1$ \\
\hline
\end{tabular}

Values are shown as mean \pm standard deviation $(\mathrm{SD}) ; \mathrm{PCV}=$ pressure-controlled mechanical ventilation; $\mathrm{VCV}=$ volume-controlled mechanical ventilation; $\mathrm{HR}=$ heart rate; $\mathrm{MAP}=$ mean arterial pressure; Ppeak = peak inspiratory pressure; Pplateau = plateau inspiratory pressure; etCO2 = end-tidal $\mathrm{CO} 2 ; \mathrm{SpO} 2$ = arterial oxygen saturation

Table 3. Hemodynamic and respiratory data of patients with BMI >25 obtained at three time intervals: $T 1-15$ minutes after tracheal intubation; T2 - 30 minutes after tracheal intubation; and T3 - 45 minutes after tracheal intubation

\begin{tabular}{|c|c|c|c|c|c|c|}
\hline & \multicolumn{2}{|l|}{ T1 } & \multicolumn{2}{|l|}{$\mathrm{T} 2$} & \multicolumn{2}{|l|}{ T3 } \\
\hline & $\begin{array}{l}\mathrm{PCV} \\
(\mathrm{n}=30)\end{array}$ & $\begin{array}{l}\mathrm{VCV} \\
(\mathrm{n}=30)\end{array}$ & $\begin{array}{l}\mathrm{PCV} \\
(\mathrm{n}=30)\end{array}$ & $\begin{array}{l}\mathrm{VCV} \\
(\mathrm{n}=30)\end{array}$ & $\begin{array}{l}\mathrm{PCV} \\
(\mathrm{n}=30)\end{array}$ & $\begin{array}{l}\mathrm{VCV} \\
(\mathrm{n}=30)\end{array}$ \\
\hline $\mathrm{HR}$, (beats/min) & $76 \pm 15$ & $79 \pm 16$ & $73 \pm 14$ & $78 \pm 11$ & $72 \pm 14$ & $75 \pm 10$ \\
\hline MAP (mm Hg) & $98 \pm 17$ & $93 \pm 12$ & $103 \pm 13$ & $106 \pm 20$ & $102 \pm 13$ & $99 \pm 11$ \\
\hline Ppeak $\left(\mathrm{cm} \mathrm{H}_{2} \mathrm{O}\right)$ & $18 \pm 4$ & $21 \pm 3^{*}$ & $18 \pm 4$ & $22 \pm 2^{*}$ & $19 \pm 4$ & $22 \pm 2^{*}$ \\
\hline Pplateau $\left(\mathrm{cm} \mathrm{H}_{2} \mathrm{O}\right)$ & $18 \pm 4$ & $19 \pm 2$ & $18 \pm 4$ & $20 \pm 3$ & $18 \pm 4$ & $20 \pm 2$ \\
\hline etCO2 (mm Hg) & $31 \pm 2$ & $32 \pm 4$ & $30 \pm 2$ & $32 \pm 4$ & $30 \pm 2$ & $31 \pm 4$ \\
\hline $\mathrm{SpO} 2(\%)$ & $99 \pm 1$ & $99 \pm 1$ & $99 \pm 1$ & $99 \pm 1$ & $99 \pm 1$ & $99 \pm 1$ \\
\hline
\end{tabular}

Values are shown as mean \pm standard deviation $(\mathrm{SD})$; $\mathrm{PCV}=$ pressure-controlled mechanical ventilation; $\mathrm{VCV}=$ volume-controlled mechanical ventilation; $\mathrm{HR}$ = heart rate; $\mathrm{MAP}=$ mean arterial pressure; Ppeak = peak inspiratory pressure; Pplateau = plateau inspiratory pressure; etCO2 = end-tidal $\mathrm{CO} 2 ; \mathrm{SpO} 2$ = arterial oxygen saturation; *statistically significant differences between the groups 
nificant yet not statistically significant $(\mathrm{p}=0.065)$ difference was found in Pmean 15 min after tracheal intubation, which was higher in the PCV group of patients. When we compared patients with $\mathrm{BMI}>25$ (Table 3), we found significantly higher Ppeak at all time intervals (T1, T2 and T3) in the VCV group. Other measured parameters were of similar characteristics.

\section{Discussion}

Because of the widespread prevalence of laparoscopic surgeries and the specific conditions they create in human body (development of pneumoperitoneum with negative effects on respiratory mechanics), it is extremely important to find an appropriate mode of mechanical ventilation for this type of surgery.

In this study, we decided to include all patients regardless of body weight or existing chronic diseases, with the history of chronic respiratory diseases as the only exception. Doing so, we hoped to get a representative sample that could be applied to almost the entire population, in contrast to the studies that targeted strictly specific groups of patients ${ }^{1,5,6}$.

In addition to studies involving laparoscopic abdominal surgery, PCV was the subject of research in thoracic surgery as well ${ }^{8-12}$. In all of these studies, PCV has been reported to be more or less superior to VCV. The results recorded in our study showed no significant benefits of PCV over VCV (Table 2), but revealed no shortcomings either. MAP was slightly higher in the PCV group at all three time intervals (T1, T2 and T3), but the difference was not statistically significant. On the other hand, HR was continuously higher in $\mathrm{VCV}$, but without statistical significance, which was consistent with the findings reported in other studies. Creating a pneumoperitoneum can cause hemodynamic changes, which according to Mercat et al. ${ }^{13}$ are potentiated by higher mean inspiratory pressure of PCV. However, we observed no significant differences, which according to Balick-Weber et al. ${ }^{14}$ could be due to the small magnitude of those changes. Respiratory parameters measured in this study showed no significant differences either. Ppeak and end-tidal $\mathrm{CO} 2$ concentration were slightly higher in the VCV group at all three measurements, whereas Pplateau was higher in the PCV group. These results are somewhat different from the study by Tyagi et al., which addressed the same topic ${ }^{4}$. The measured $\mathrm{SaO} 2$ varied among intervals and these results were not quite in line with the analysis of other authors ${ }^{5}$, especially when it comes to specific groups of patients ${ }^{1}$. The values of all these parameters were within the normal range.

Given that $\mathrm{CO} 2$ insufflation into the abdominal cavity (creation of pneumoperitoneum) leads to caudal displacement of the diaphragm, lowers functional residual capacity and lung compliance, and increases resistance of the lung tissue, which is especially pronounced in obese and those with chronic respiratory diseases, we decided to establish a subgroup of patients with BMI $>25 \mathrm{~kg} / \mathrm{m}^{2}$ and compare their data as well (Table 3). The patients with BMI $>25 \mathrm{~kg} / \mathrm{m}^{2}$ are particularly interesting in this case because obesity is associated with reduced functional residual capacity of the lungs, lung compliance and oxygenation index, while increasing the overall resistance of the respiratory system ${ }^{16}$.

When we included the above criterion (BMI $>25$ $\left.\mathrm{kg} / \mathrm{m}^{2}\right), 19$ patients remained in PCV group and 12 patients in VCV group. Hemodynamic parameters remained without significant changes. There was slightly higher $\mathrm{HR}$ on all three measurements in VCV group and higher MAP in PCV group, with almost identical dynamics in comparison with the original groups. Accordingly, there were no significant effects of pressure or volume ventilation on hemodynamic parameters in obese patients, which is consistent with the existing literature ${ }^{6,16,18-19}$.

Comparing respiratory parameters, we found that Ppeak was significantly higher in VCV group, especially on T2 and T3 measurements $(p \leq 0.01)$. This is important because lower inspiratory pressures have a favorable effect on patient hemodynamics and reduce the incidence of barotrauma ${ }^{13}$. It should be noted that most authors state just this variable as one of the main strengths of $\mathrm{PCV}^{1,4,5,7,17,19}$, although there are examples in the literature that deny this advantage ${ }^{14,16,18}$. Pplateau was also, although not significantly lower in PCV group at all three measurements, and it is inconsistent with the findings obtained in the initial processing of data which involved all patients regardless of BMI. A1though available studies do not indicate statistically significant differences in Pplateau values ${ }^{5,14}$, the dynamics obtained here raises the question of whether the results are just a matter of pure coincidence or there really is a link with BMI values. According to 
these results, we can theorize that the increase in BMI leads to lower Ppeak and possibly Pplateau values with $\mathrm{PCV}$, which is somewhat different compared to similar studies.

End-tidal $\mathrm{CO} 2$ (etCO2) results showed similar dynamics. In the original groups, etCO2 was slightly lower, but not significantly, in the PCV group at all measuring intervals, and a comparable pattern was also recorded in the groups with $\mathrm{BMI}>25 \mathrm{~kg} / \mathrm{m}^{2}$. Yet, it should be noted that the difference between the observed groups increased without reaching statistical significance. Some authors confirmed lower etCO2 values in $\mathrm{PCV}$ patients ${ }^{1}$, although there are studies in which there was no significant difference ${ }^{5,712,19}$ and studies that favor $\mathrm{VCV}^{18}$.

Arterial oxygen saturation measured by pulse oximetry showed no significant between-group difference. It was to be expected, since all patients were without previous history of chronic respiratory diseases, with good preoperative values. Also, most previous studies found no significant differences either ${ }^{1,18,19}$. The only exception to the above is the study by Lin et al., who report on better intraoperative and postoperative oxygenation with PCV in elderly patients with poor pulmonary function ${ }^{11}$.

\section{Conclusion}

Based on the results, we conclude that PCV and $\mathrm{VCV}$ were equally effective in maintaining adequate ventilation, oxygenation and hemodynamic stability in the study groups of patients. However, comparison of obese patients $(\mathrm{BMI}>25)$ showed particular advantages of PCV (lower peak pressure, lower end-tidal $\mathrm{CO}_{2}$ ) which, given the present pace of change, should be additionally investigated. It would also be interesting to see how chronic respiratory diseases affect this issue, which, we believe, is still insufficiently investigated.

\section{References}

1. Šurbatović M, Vesić Z, Djordjević D, Radaković S, Zeba S, Jovanović D, et al. Efekti mehaničke ventilacije kontrolisane pritiskom kod osoba sa oštećenjem respiratorne funkcije tokom laparoskopske holecistektomije. Vojnosanit Pregl 2013;70: 9-15, doi:10.2298/VSP1301009S. (in Serbian)

2. Richardson PB, Krishnan S, Janakiraman C, Wilkes AR, Hodžović I. Extubation after anaesthesia: a randomised comparison of three techniques. Acta Clin Croat. 2012;51:529-36.
3. Bogdanović Dvorščak M, Lupis T, Adanić M, Pavičić Šarić J. Akutni respiracijski distresni sindrom i drugi respiracijski poremećaji u sepsi. Acta Med Croat. 2015;69:167-75. (in Croatian)

4. Tyagi A, Kumar R, Sethi AK, Mohta M. A comparison of pressure-controlled and volume-controlled ventilation for laparoscopic cholecystectomy. Anaesthesia. 2011;66:503-8, doi:10.1111/j.1365-2044.2011.06713.x.

5. Cadi P, Guenoun T, Journois D, Chevallier J-M, Diehl J-L, Safran D. Pressure-controlled ventilation improves oxygenation during laparoscopic obesity surgery compared with volume-controlled ventilation. Br J Anaesth. 2008;100:709-16, doi:10.1093/bja/aen067.

6. Ogurlu M, Küçük M, Bilgin F, Sizlan A, Yanarates O, Eksert S, Karasahin E, Cosar A. Pressure-controlled vs volume-controlled ventilation during laparoscopic gynecologic surgery. J Minim Invasive Gynecol. 2010;17:295-300, doi: 10.1016/j.jmig.2009.10.007.

7. Montes FR, Pardo DF, Charrís H, Tellez LJ, Garzón JC, Osorio $\mathrm{C}$. Comparison of two protective lung ventilatory regimes on oxygenation during one-lung ventilation: a randomized controlled trial. J Cardiothorac Surg. 2010;5:99, doi:10.1186/1749-8090-5-99.

8. Tuğrul M, Camci E, Karadeniz H, Sentürk M, Pembeci K, Akpir K. Comparison of volume controlled with pressure controlled ventilation during one-lung anaesthesia. Br J Anaesth. 1997;79:306-10.

9. Pardos PC, Garutti I, Pińeiro P, Olmedilla L, de la Gala F. Effects of ventilatory mode during one-lung ventilation on intraoperative and postoperative arterial oxygenation in thoracic surgery. J Cardiothorac Vasc Anesth. 2009;23:770-4, doi: 10.1053/j.jvca.2009.06.002.

10. Hu X, Shen H, Li X, Chen J. Effects of volume-controlled ventilation and pressure-controlled volume-guaranteed mode during one-lung ventilation on circulation, pulmonary function and lung injury. Zhonghua Yi Xue Za Zhi. 2014;94:1006-9.

11. Lin F, Pan L, Huang B, Ruan L, Liang R, Qian W, Ge W. Pressure-controlled versus volume-controlled ventilation during one-lung ventilation in elderly patients with poor pulmonary function. Ann Thorac Med. 2014;9:203-8, doi: 10.4103/1817-1737.140125.

12. Song SY, Jung JY, Cho MS, Kim JH, Ryu TH, Kim BI. Volume-controlled versus pressure-controlled ventilation-volume guaranteed mode during one-lung ventilation. Korean J Anesthesiol. 2014;67:258-63, http://dx.doi.org/10.4097/kjae.2014.67.4.258.

13. Mercat A, Graïni L, Teboul JL, Lenique F, Richard C. Cardiorespiratory effects of pressure-controlled ventilation with and without inverse ratio in the adult respiratory distress syndrome. Chest. 1993;104:871-5.

14. Balick-Weber CC, Nicolas P, Hedreville-Montout M, Blanchet P, Stéphan F. Respiratory and haemodynamic effects of volume-controlled vs pressure-controlled ventilation during 
laparoscopy: a cross-over study with echocardiographic assessment. Br J Anaesth. 2007;99:429-35, doi:10.1093/bja/aem166.

15. Pelosi P, Croci M, Ravagnan I, Tredici S, Pedoto A, Lissoni A, Gattinoni L. The effects of body mass on lung volumes, respiratory mechanics, and gas exchange during general anesthesia. Anesth Analg. 1998;87:654-60.

16. Aldenkortt M, Lysakowski C, Elia N, Brochard L, Tramèr MR. Ventilation strategies in obese patients undergoing surgery: a quantitative systematic review and meta-analysis. Br J Anaesth. 2012;109:493-502, doi:10.1093/bja/aes338.

17. Davis K Jr, Branson RD, Campbell RS, Porembka DT. Comparison of volume control and pressure control ventilation: is flow waveform the difference? J Trauma. 1996;41:808-14.
18. De Baerdemaeker LE, Van der Herten C, Gillardin JM, Pattyn P, Mortier EP, Szegedi LL. Comparison of volume-controlled and pressure-controlled ventilation during laparoscopic gastric banding in morbidly obese patients. Obes Surg. 2008;18:680-5, doi: 10.1007/s11695-007-9376-8.

19. Hans GA, Prégaldien AA, Kaba A, Sottiaux TM, DeRoover A, Lamy ML, Joris JL. Pressure-controlled ventilation does not improve gas exchange in morbidly obese patients undergoing abdominal surgery. Obes Surg. 2008;18:71-6.

20. Prella M, Feihl F, Domenighetti G. Effects of short-term pressure-controlled ventilation on gas exchange, airway pressures, and gas distribution in patients with acute lung injury/ARDS: comparison with volume-controlled ventilation. Chest. 2002; $122: 1382-8$

Sažetak

\section{UTJECAJI TLAKOM I VOLUMENOM KONTROLIRANE STROJNE VENTILACIJE NA HEMODINAMSKE I RESPIRACIJSKE PARAMETRE BOLESNIKA TIJEKOM LAPAROSKOPSKE KOLECISTEKTOMIJE}

\section{Mihalj, D. Vladić, Z. Karlovic, Ž. Zadro i V. Majerić Kogler}

Učinak intraoperacijske strojne ventilacije na pojavu poslijeoperacijskih plućnih komplikacija se intenzivno istražuje posljednjih nekoliko godina. Potencijalne prednosti tlačno kontrolirane (PCV) u odnosu na volumnu (VCV) strojnu ventilaciju tijekom laparoskopskih operacija još uvijek nisu u potpunosti dokazane. U istraživanje je bilo uključeno 60 bolesnika u dobi od 18 do 70 godina, planiranih za laparoskopsko odstranjenje žučnog mjehura. Svi bolesnici su imali indeks tjelesne mase $\leq 35$, ASA I.-III., bez povijesti kroničnih respiracijskih bolesti. Slučajnim su odabirom podijeljeni u skupine s tlačnom odnosno volumnom ventilacijom. Dobiveni rezultati nisu pokazali značajnih razlika u respiracijskim i hemodinamskim parametrima između skupina. Kada su izdvojeni i uspoređeni bolesnici s indeksom tjelesne mase $\geq 25$ zabilježen je značajno niži vršni tlak u bolesnika s tlačno kontroliranom ventilacijom u 15. (18,52 prema 21,83 cm H2O, p=0,022), 30. (18,73 prema $21,83 \mathrm{~cm} \mathrm{H} 2 \mathrm{O}, \mathrm{p}=0,009)$ i 45 . (18,94 prema $22,667 \mathrm{~cm} \mathrm{H} 2 \mathrm{O}, \mathrm{p}=0,010)$ minuti nakon trahealne intubacije. Ostale vrijednosti su bile bez statističke značajnosti. Može se zaključiti da između PCV i VCV ne postoje značajnije razlike u održavanju odgovarajuće ventilacije i oksigenacije bolesnika te hemodinamske stabilnosti u promatranim skupinama bolesnika. Međutim, usporedba bolesnika s prekomjernom tjelesnom težinom je pokazala određene prednosti PCV-a koje bi s obzirom na prisutnu dinamiku promjena trebalo podrobnije istražiti.

Ključne riječi: Respiracija, umjetna; Laparoskopija; Anestezija, opća; Intubacija, endotrahealna; Respiracija; Pretilost; Prikazi slučaja 